Pakistan Journal of Humanities and Social Sciences

April - June 2018, Volume 6, No. 2, Pages 248 - 262

\title{
The Role of Socio-Cultural Factors in Informal Cross-Border Flows between Borderland Communities of Nigeria and Niger Republic: The Case of Illela-Birni N'konni International Border Communities
}

\author{
Abubakar Liman ${ }^{1}$ \\ ${ }^{1}$ Department of Political Science, Federal University Dutsinma, Katsina State \\ Email: aliman@fudutsinma.edu.ng
}

\begin{abstract}
This study examines the contributions of socio-cultural factors towards promoting informal cross-border flows between international borders dividing Nigeria and Niger republic. It did so by focusing on the micro zone of Illela (Nigeria) and Birni N'Konni (Niger republic).The study discovered that, despite colonial division, both communities still retain their sociocultural values and still employ it in fostering their relations outside the official circle. The research concluded that if adequately utilised, informal cross-border flows between the two communities can be used to build a security network beyond the official realm.
\end{abstract}

Keywords: Informal Cross-Border Flows

\section{Introduction}

Although Africa had welcomed and celebrated the end of colonialism and the ushering in of new independent states in the continent, the end of colonialism was not without challenges to the territorial integrity of African states. In fact, instead of these inherited borders to serve their traditional essence, they became the source of frequent cause of war and conflicts among the nation-states. This is because most these borders were not only poorly defined in the documents; they lack any evidence of demarcation on ground (Zartman, 1965). Today Africa has at least 109 boundaries with an approximate length of 28,000 miles, dividing 177 cultural groups and providing only one official crossing point for every 80 miles (Okunmu, 2016) and above all, with thousand other illegal crossing points. This has made the African border areas a friendly environment for the smuggling of illegal goods, human trafficking and even cross-border terrorism (as in the case of Boko Haram in West Africa and Lord Resistance Army in East Africa and Al-Qaida in the North Africa, etc).

Despite the security threats and other challenges associated with informal crossborder activities in the continent, the area provide for the academics, especially those with 
interest in informal cross-border activities, an avenue for the understanding of the conditions of African international borders as well as the relationships that exist between border communities This is far more interesting in West Africa where dozens of traditional communities were forced to live side-by-side of two independent political entities. Nigeria being the most populous and most diverse country in the continent provides a sound area of investigation. Virtually all its tribal and ethnic formations along its border areas share sociocultural affinities with their counterparts in the neighboring country. To cite a few, the Yoruba people of Western Nigeria and those of Benin republic and Togo; the Kanuri, Shuwa, Fulani and other minority tribes in the North East and their counterparts in Cameroon, Niger and Chad; the Hausa, Fulani. Djarma, Touregs in North Western Nigeria and their counterparts in Niger and Benin republic are typical example of this colonial division.

However, instead of the colonial borders to create divide between them, the sociocultural relations between them became a factor that further re-enforce their relations and promoted cross-border flows between the border areas. It is view of this that this paper examines the role played by socio-cultural factors in enhancing cross-border flows between two international border communities of Nigeria and Niger republic. It did so by specifically focusing on the border communities of Illela (Sokoto, Nigeria) and Birni N'Konni (Tahoua, Niger). The choice of these micro communities is basically carried out with a view to having deeper understanding and providing a contextual description of the kinds of relationships and activities that exist between the colonial divided African border communities and the challenges therein.

The paper is divided into five sections. Section one is discussed. Section two deals with the methodology employed in the process of data collection. Section three captured the study area. Section four is composed of the Brief history of Illela and Birni 'Nkonni border community. Section five examines the role of socio-cultural factor in cross-border flows between the two communities. Section six concluded the work

\section{Methodology of the Work}

This is basically a qualitative research. The respondent of this research constitute all those who engage carrying out socio-cultural activities between the two borderlands of Illela and Birni N'Konni. Interview and personal observation of the study area was the main instrument used in data collection. The interview was carried out on traders, farmers, traditional rulers, border security, etc. These people were selected because of their face-toface contact with the realities of cross-border flows in the area. The study adopted two basic 
sampling methods; opportunistic and snowball sampling procedures. In opportunistic sampling interviews were collected from respondents who were ready to cooperate, they were then asked to refer to a respondent(s) who is conversant with the study area (snowballing). This was carried out until the chain of respondent is completed. Interviews carried out were based on face-to-face format. The interviews were further complemented by personal observation of the study area. The unwillingness of many respondents to be willing to provide detail information due to suspicion as well as the virtual absence or willingness on the part of the security agents to assist the research with relevant statistical data failed. These constitute some key limitation of the research.

\section{A. Study Area}

The two communities are located eight kilometres from one another. Illela is located between latitudes $13^{\circ} 40^{\prime} \mathrm{N}$ and $5^{\circ} 20^{\prime} \mathrm{E}$ while Birnin N'Konni is located on longitude $13^{\circ}$ $55^{\prime} \mathrm{N}$ and $5^{\circ} 20^{\prime} \mathrm{E}$ (wikipedia, Nuhu-Koko, 1989) making the two communities to live eight kilometres apart. Illela is the headquarters of Illela local government and one of the 23 local governments of Sokoto state. To the North, it shares border with Birni-N'Konni town of Tahoua region of Niger Republic and Gwadabawa Local Government area to the south, Gada local government area to the East and Tangaza local government to the west. The local government was one of the many local governments created carved out of Gwadabawa local government in 1989. It has an area of 1,049 (one thousand and forty-nine) square kilometres and with an estimated population of 150,498 (One hundred and fifty thousand four hundred and ninety-eight) based on 2006 census. (Illela Leeds, 2008).

The Hausa people constitute the majority of the people of the area. There are also exist indigenous nomadic Fulani and Tuareg. The occupation of the majority of Hausa people include farming and commerce while the Fulani and the Tuareg who are largely herdsmen engaged rearing camels and goats and are mostly found in Northern part of Illela close to the border with Birni-N'Konni (Illela Leads, 2008).

The topography of Illela could be divided into two: semi arid and grassland areas In the Northern part, towards Birni-N'Konni, the topography is more of semi arid, mostly covered by sparse drought resistant shrubs interspersed with area of bare rock or sandy ground. However, in the southern part especially towards Gwadabawa, the area is largely a grassland area covered with scattered bushes and shrubs. Both in the North and in south, the land has yellowish, sandy soil that is deficient in nutrients but relatively suitable for the 
production of cereals like millet and cowpea. (Illela Leeds, 2008). This means that these cereals and their types serve as the largest number of crops produced in the areas

Located in the in Sahel savannah area, the temperature of Illela covers between $40^{\circ} \mathrm{C}$ in the hottest months and $26^{\circ} \mathrm{C}$ in the coolest months. The annual rainfall of Illela covers between 600 to 650 millimeters in less than five months which is usually followed by long dry season. Hence, farmers from Illela utilize the Lake Kalmalo, River Rima and River Sokoto to supplement seasonal rainfall by providing for irrigation, grazing, and water feeding and watering animals (Illela Leeds; 2008:18). Trees and plants available in the area include Shea butter, Tamarind "sabara", "kalgo" and other various species of acacia. All of which are adaptive to the long dry season of the area (Iliya, 1989:39).Nonetheless, the area is threatened by growing desert encroachment, and severe cutting of trees especially as both Illela and Birnin-N'Konni depend on woods from Illela.

Politically, Illela has two districts and several villages that are traditionally administered. The districts include: Illela and Kalmalo while villages include: Araba, Gidan Hamman, Kalmalo, Darna Tsolawo, Darna-Sabon Gari, Gidan Katta, Galti and Totai (Illela Leeds, 2008).

Birni N'konni is a border community with an approximate population 44,663 (2001 census). It is located in the extreme south of Tahoua region of Niger Republic and shares border. (Wikipedia encyclopaedia, n.d). The contemporary importance of this town to Niger Republic lies in its vast arable land for cultivation and rearing. In fact, it is one of the most renowned communities' border communities in Niger republic. This is not far away from its being a gateway and a source of entry of goods from Nigeria. Therefore, its geographical position in Niger, (bordering Nigeria) gives it an economic advantage. Apart from its road link to Illela, it also serves as an important link to important cities of Niger such as Maradi, Niamey, and Zinder.

Birni-N'Konni is situated on a high plain, 560, meters above the sea level. It also covers a landmass of 661 square kilometres. To the North, are the town of Allela and Madawa and Dogondutchi to the east (Jip. 1996:59)? The town is occupied by several ethnic groups such as the Adarawa and Gobirawa Hausa people (who constitute the majority), Kanuri, Fulani, and Azbinawa, (the light completion Tuareg) (Jip, 1996; 59: Shehu, 2004; Encyclopaedia Encarta, 2009; Tanko, R.M, personal communication, July 29, 2009). 


\section{A Brief History of the Two Border Communities}

\section{A. Illela, Nigeria}

Historically, Illela is an offshoot of "Birni-N" Konni" (the walled city of Konni). Founded since in the pre-Jihad era around 1804, the history of the community according to the Illela people were believed to have migrated from Saudi Arabia to some place around Egypt and settle at Zamfara from where they moved to Alkalawa in Gobir. it was said that the activities of flood, and human raiders in the area as well as the frequent wars between Asben and Gobir, they were forced to leave their settlement to a place near Lake Kalmalo, six kilometres west of Illela town (Samaila, 2009: 34-36). Shehu Usmani Dan Fodio, the $21^{\text {st }}$ century reformist of Hausaland was the one who advised the people in the area to move to their present destination around the present Birnin N'Konni (Shehu, 2004). In compliance to his statement, the leaders of the people ask them to move to "Mullela", meaning a safer place. However, in a different version, Archibong, M. (August 9, 2009) noted that the word Illela originates from the name Allela and it is popularly believed that the town was founded by one Allela after he was sent away from Birni-N'Konni as a result of disobedience to the then ruler. It can, however, be argued that it was Konni who sent him out since according to Ubandawaki, (personal communication, July 29, 2009), Konni, Allela and Kalmalo were blood relatives. Birnin N'Konni could, therefore, be the brother or uncle to Allela. Until the arrival of $19^{\text {th }}$ century Islamic jihadists, Illela was part of Gobir Kingdom, which later became under Sokoto caliphate. Moreover the 1904 and 1906 colonial treaties between Britain and France finally divided the two communities under the political control of the two colonial states. (Odihi, 1989).

The traditional title Ilella is headed by a traditional district head popularly referred to as "Sarkin Rafin Illela." He is however, assisted by palace officials who are appointed to carry out duties several duties on behalf of Sarkin Rafin Illela. They include "Ajiya" (treasurer), "Sarkin Fawa" (head of butchers), "Sarkin Baki" (chief visitor attendant), "Sarkin Makera" (chief black smith), "Sarkin Aski“(chief barber), "Sarkin Dogarai” (chief security of the palace) etc. The ubandawaki is furthermore assisted "Mai-Unguwa" (head of an area in a village or town). The traditional rulers of Illela are listed as follows:

1. Muhammadu Ubandawaki Matankari Dalisa

$1817-1821$

2. Ubandawaki Muhammadu Mustapha

$1821-1883$

3. Muhammadu Ubandawaki Awkin Karu

1883-1890

4. Ubandawaki Idi

1890-1903

5. Usman Ubandawaki

1903-1920 
6. Ubandawaki Bako

7. Ubandawaki Isah Gada

8. Ubandawaki Muhammadu Dan Aljimmo

9. Malam Abdullahi Dan Barau

10. Abdullahi Dan Barau

11. Alhaji Isah Umar Muhammadu

12. Muhammadu Tukur Abdulrahman
1920-1946

1946-1970

1970-1977

1978-1980

$1978-1980$

1980-2001

2001-date

However, according to Shehu (2004), since 2001, the Sokoto state government divided Illela into two districts, illela and Arewa district. Illela falls under the jurisdiction of The Sarkin Rafin Illela with the following villages under his jurisdiction. They include: Kalmalo, Damba, Darnar Tsolawo, Kiliya. Tarke, Gaidau and Gidan Katta, etc. The other communities are not within the justification of this study.

\section{B. Birni N'Konni, Niger Republic}

As earlier stated, Illela was an offshoot of Birni-N'Konni. The city was said to have been founded between $15^{\text {th }}$ and $16^{\text {th }}$ century and since then, the capital city has been moved to different places. The first city was Nadabar then Nadaba and finally to its present place (1922-1923).the city which was equally under the rule of Sarkin Gobir, was a city that was surrounded by wall which was then use as a defense shield against external aggression and raiders. The city which was defeated by the forces of Sokoto caliphate in 1804 became the vassal of Sokoto caliphate (Jip, 1996; 65). Colonialism moreover took it away from Sokoto caliphate after the defeat of Sokoto caliphate. Birni-N'Konni was however known for the French brutal massacre of innocent people on May 8, 1899 under the French Voulet Chaname Mission (wikipedia Encyclopedia, n.d).

"Sarkin Konni" (the traditional ruler of Birni-N'Konni) currently heads BirniN'Konni town. As in Illela, The Sarkin Konni is assisted by the "Waziri" (the chief official and advisor), "Ajiya" (tresurer), "Magajin Gari" (representative of the king), "Sarkin Baki" (chief visitors attendant), "Sarkin Aski" (chief barber), "ubandawaki” (head of calvary), "Yari” (head of prisons), "Sarkin Dogarai" (chief security), "Sarkin Fawa" (chief butcher), (chief market official), etc.

Birni-N'Konni, since its inception had recorded a number of traditional rulers; Jip (1996) listed the traditional rulers from 1756-1988 while Ahmed Aliyu (interview, 2010) stated the name of the current traditional on seat. The followings are the list of Konni traditional rulers from 1756 to date: 


$\begin{array}{lll}\text { Maman Banka } & - & 1756-1793 \\ \text { Chaibou Mairaba } & - & 1793-1821 \\ \text { Ibrahim Chaibou Gourama } & - & 1821-1891 \\ \text { Adam Ibrahim Gourama } & - & 1891-1898 \\ \text { Muhammadou Ibrahim Gourama } & - & 1898-1903 \\ \text { Madidi Mainassaur } & - & 1903-1915 \\ \text { Alou Ibrahim Gourama } & - & 1915-1917 \\ \text { Ousmane Ani } & - & 1917-1924 \\ \text { Arzika Adam } & - & 1925-1955 \\ \text { Elhadji Hassane Ousmane } & - & 1955-1983 \\ \text { Elhadji Alou Arzika } & - & 1983-1988 \\ \text { Moumaini Hassane } & - & 1988-2009 \\ \text { Muhammadou Salihou } & - & 2009 \text {-date }\end{array}$

Politically, Niger Republic is a state divided into several administrative units for effective and efficient administration. First, the country is divided into regions (such Agadez, Tahoua, Dosso, etc). Each region is divided into departments (such as Birni-N'Konni). Each department is divided into communes (districts) and each commune is divided into villages. The department of Birni-N'Konni has seven communes (districts) and several villages under its administration. The communes include Allela, Begaza, Birni-N'Konni, Dougueraoua, Malbaza, Allaye and Tsernaoua. Birni N'Konni commune has 35 villages under it. They include; Agglomeration B. Konni, Dbbisou, Guidan Tondou, Gusaou, Saouna Bawa, Saouna Tsilo, Zata, to mention but a few. (CENI, 2003).

\section{The Role of Socio-Cultural Factors in Enhancing Informal Cross-Border Flows between Illela and Birni N'konni International Border Communities}

We noted that Illela and Konni were said to be formed by to two brothers. This defined their history as the history of brothers. This was however easily kept due to their close proximity. The closer proximity between the two communities led their continuous contact thereby maintaining the relationships between them. One of such relationship is intermarriage. Buba and Danmaliki (interview, 2009) noted that inter-marriage between the two communities not only support cross-border flows; it reduced the extent to which conflict is being managed by the duo communities. They pointed out that there is virtually no individual in Birni-N'Konni or in Illela that is without a relative, friend or business partner across the border and as for Ubandawaki (interview, 2009), a day does not come to pass without people from either side of the border crossing to attend to family affairs. At the time of the interview, the Chairman of illela local government and the Secretary to the Department of 
Birni N'Konni were all said to be having families across the border. In fact, the chairman of Illela Local government was having two wives; one in Illela and the other in Birni N'Konni.

At the border post, it is easy to observe the movement of men, women, and children in cars, on motorcycles, bicycles and donkeys paying visits to their relatives on either sides of the border (field notes, 2009) without being asked any passport or document. On the contrary, all alien faces are interrogated and were asked to duly meet the strict condition for border crossing (personal observation, 2018). This indicated that even the security at the border post have adopted a segregator method of distinguishing the citizens of the two border communities as opposed to non-border citizens. Ladan (interview, 2009) and Toyon (interview, 2009), the two been the chief security officers of immigration and custom in the border post, admitted that the reason for allowing such free movement of people of the border areas and their goods is due to the shared socio-cultural ties between them, especially intermarriages. Ladan (interview, 2009) added that they were quite aware that people in the border areas do cross without documents or interrogation. This is done "at the discretional powers of the immigration officials."

Youths in both sides of the borderland engage in active cross-border marriage activities. Youths getting married usually invite their friends and relatives from the other side of the border for a meeting or ceremony. In turn, their friends and relatives participate as well as support the bridegroom with moral and financial assistance. Young girls getting married also have their friends and relatives crossing the border to celebrate with them (Garba, interview 2009). Inter-marriages can therefore be seen as a very strong instrument of enhancing the flows of people between the two international communities.

The vast majority of the people of both communities are Muslim. Although there exist indigenous Christians but their number is insignificant. Most of the regious group in both Illela and Birni N'Konni are foreigners, mostly from the southern parts of Nigeria (like the Igbos and Yorubas, etc). There exist a significant numbers of religious movements and sect like Qadiriyya, Tijjaniya, Izala and Shia. The cross-border flows between these groups is largely observed during their festivities or preaching session. As for the Tijjaniyya, their mass movements are usually observed during Maulud (celebration of the Prophet Muhammad's birthday). This is achieved through invitation by members from either side of the border community to celebrate with them. Another mass annual cross-border movement among the members of this group includes visitations to Tijjaniya movement in Chota (Niger republic) and Senegal. This was either carried out jointly by relative in both side or by Nigerians 
crossing into Niger republic... As for Izala, they are popularly known for their preaching sessions (Da'awah). During such sessions in either Illela or Birni-N'Konni, members from both sides cross the border to converge at a stipulated place scheduled for the preaching to take place, sometimes taking a whole night or even days. The preaching season which is usually carries out by scholars from both sides is usually met with large attendance. It is to be noted in this regard that invitation and movement is not only by members of both communities but also include people from far and near border areas. The Shiites are known for their procession of Ashura among others. Other religious activities include paying "Sallah" homage to their religious leaders in both sides and congratulating or paying condolence visits in times of successes or grief (Shehu, interview 2010).

Being two international border communities with shared cultures, it is not unlikely to find the communities attracted to one another traditional activities. In both communities traditional institution play a significant role in cross-border flows? One of such activities is the turbaning ceremony. Such turbaning may be that of a traditional head or any of the palace officials. Others include marriage, naming, and birth ceremonies as well as condolence visits of traditional ruler's families attract people to cross the border in order to attend (Ubandawaki, interview 2009). This has proven that the traditional institutions of the area play essential role in enhancing cross-border flows.

These traditional institutions are also respected not only for fostering cordial relations between the two communities but also in the control of cross-border crimes and disputes. Cross-boer crime such as theft, disrespect for international law by individuals or group is in most cases resolved by traditional institutions. The beauty of these institutions is that they are respected by official institutions in either side of the border. During the research in the area, it is observed in Nigerian part of the border how an arrested Nigerien motorcyclist who was said to have committed a crime in the Nigerian soil was released on the interference of a low level palace official from Birni N'Konni. This indicated that traditional institutions not only play a significant role in managing cross-border flows but also cross-border security. Ladan noted that through traditional ruler's criminals who committed crime in either side or the cross to prevent justice usually have themselves returned through the traditional leaders in order to be prosecuted in their place of crime. Disputes between farmers and cattle rearers from either side are usually by traditional leaders and security. It is usual that rearers from Birni-N'Konni cross the border to the greener areas of Illela to graze their animals. Accidentally or deliberately, they sometimes cross into farmlands and destroy crops which usually cause 
disputes that sometimes claim lives and properties. Such disputes are best managed by the traditional institutions who come together to pass verdict and punish defaulters. They also provide frameworks through which future occurrences could be checked (Ubandawaki, interview 2009). Traditional institutions therefore contributed towards reducing state interference on issues that might involve strict administrative protocols if the governments of both sides are to get involved.

Ladan (interview, 2009) pointed out that although cross-border crime is minimal in the area, the role played by traditional rulers has strengthened the border administration in the area. He affirmed that the traditional rulers of both attend the joint bi-monthly security meetings between all the representatives of Nigerian and Niger border securities officials. This case, traditional rulers involve in the arrest of such criminals who are then sent back to the authorities of their community for prosecution.

Security meetings between security agencies from both sides not only help in facilitating understanding between agencies on both sides to resolve their problems amicably, it further enhanced cross-border outflows. Musa (interview, 2009) noted that due to the impact of such meetings security agents from both sides familiarize themselves with one another and understand how conflicts are being managed beyond the official realm. As a result of these meetings, friendships were developed among security agents and community representatives. This share of understanding plays a significant role in facilitating crossborder flows not only between the communities but also among community leaders. Due to such relationship developed, the security agents from both sides cross in their uniform to visit their counterparts and community leaders.

The ability of Illela market to provide variety of goods for the people of the region only attracts the civilians of Birni-N'Konni; Nigerien border security officials regularly cross the border to buy goods in Illela market. They are sometimes seeing in their uniforms or off uniforms. Nigerian security officials also cross into Birni-N'Konni to visit their friends in either Nigerien border post or Birni-N'Konni town (Ibrahim, interview 2009). Aliyu (interview, 2009) who happens to be member of Nigerian immigration personnel in the area affirms that a colleague of his is married to a lady in Birni-N'Konni and has been engaged in regular visit of his in-laws, sometimes with his friends.

Sport is indeed a uniting force among different people of the world. In the case of Illela and Birni-N'Konni, sport plays a significant role not only in uniting the two communities but also in enhancing informal cross-border flows. Illela is popular with 
traditional wrestling popularly known as "kokawa" while Birni N'Konni is known for its specialization in traditional boxing popularly known as "dambe". These alongside with modern sports like football have contributed in no small measure towards fostering crossborder flows from between the two communities. Such sporting activities derive great deal of support from politicians, traditional rulers, wealthy and influential individuals of both communities (Ibrahim, interview 2009).

Communication is the life wire of any successful activity in any setting. Without effective and efficient communication, the social, economic, and political life of the people will be in disarray. Communication is the medium through which the people of Illela and Birni-N'Konni maintain their relationships and it is still through communication that this relationship is improved. Apart from the official road and dozens of illegal bush routes that connect the two communities, shared mobile phone services serve as mediums through which enhances cross-border flows. Unlike Illela which has none, Birni-N'Konni champions the control of two radio stations. These radio stations have greater influence on the people of Illela than the state radio station, Rima Radio. (Bako, interview 2009). The two radio stations in Birni-N'Konni as at the period of research are "Amfani Radio" and "Sarauniyya Radio". Both radio stations provide a medium for social relations, networking, and enlightenment for the two communities. This, nonetheless, does not mean that they are the only media stations listened to in the area; rather, they represent a medium through which local issues that affect the communities are well discussed. According to Bako (interview, 2009), they organize and air programmes that further strengthen the existing relations between the two communities.

The radio stations carry out programmes such as cross-border greetings (between friends and relatives), cross-border jokes between cousins or tribes (as in the case of Fulani and Gobirawa tribes). In this regard, it is interesting to note that while the two popular radio stations are located in Birni-N'Konni, most of the activities run by the stations such as advert, preaching and music originate from Nigeria. Even Illela local government also patronizes these media houses more than it patronizes the state owned radio (Rima Radio Sokoto) (Bako, interview 2009). Hence, local politicians in Nigerian Illela prefer to utilize radio stations in Birni N'Konni than those in Sokoto.

The presence of large sum of Nigerians in Birni N'Konni and Nigeriens in Illela had facilitated informal cross-border flows across the frontiers of the two states. Standing at the Nigeria border security post, one can easily observe the regular crossing of the border by parents cross to take their children to school or kids on bicycle or motorcycle crossing to go to 
school. For instance, Nigerian school bus belonging to Yoruba community could be seen on daily on a to and fro movement conveying pupils to their respective schools in Illela or back home in Birni N'Konni. (Personal observation 2009 and 2017). Cross-border flows are not only supported by the activities of western education, traditional Islamic schools equally play a prominent role. It is noted that a large number of boys from Birni-N'Konni and other distance villages in Niger are dispatched by their parents to Islamic schools (popularly known as makarantar allo in Hausa) in search of Qur'anic education. This usually happened after the planting season when the kids have work to do at home to support their parents (Tanko, interview 2009). "Almajirci" is historically an Islamic system of education in Hausaland that accommodates students in boarding houses. These students come from far and near to learn Islamic knowledge. The students are called "Almajirai". Khalid (2006) in his study of Sokoto metropolis and its environs found out that 68.30 percent of the almajirai (students) hailed from rural areas while 27.96 percent originates from semi-urban areas. Dankama (2004) added that, the almajirai are divided into two groups: the first are those aged between 6-18 years. This group largely depended on begging as a means of sustenance. Khalid (2006) added that apart from begging, most of these students engage in other menial jobs such as serving as houseboys, washing plates in restaurants, etc. The second group consists of aged 18-35 years old, who are at ordinary and advance level of learning. This group, however, engage part of their time in mini trade, cheap laboring, and small scale production (Dankama, 2004), etc.

Although many people in Hausaland, especially among rural dwellers, believed that begging in the processes of acquiring knowledge is a holy thing, Khalid (2006:8) observed that these almajiris came backgrounds that are characterized by mass poverty, virtual absence of social and economic activities, general neglect in terms of provision of infrastructural facilities and other indices of socio-economic development. The pupils' parents are mainly low-income farmers whose annual crop production is far below requirements of their domestic consumption and expenditure.

The search for efficient but cheap health care has also being identified as a factor triggering cross-border flows between the two communities. Illela for instance, has a General hospital and three private clinics, Aminchi Nursing Home, Nasifa Clinic and Daboe clinic while in Birni-N'Konni there is only one public hospital, General Hospital Galmi. Nevertheless, despite the existence of health care systems in both sides, many people from Birni-N'Konni prefer to cross to Illela for medical care. The reason being that health care 
system is cheaper on the Nigerian part than in Niger soil. For example, while buying hospital card in Illela clinics may cost a patient between 200 to 300 hundred naira, in Birni-N'Konni, it cost around 700 to 800 the value of Nigerian naira. Similarly, the drugs on the Nigerian side of Illela are cheaper when compared to the officially approved drugs in Niger republic which are mostly expensive foreign drugs (mostly from France). It could therefore be said that the price differentials and accessibility of hospitals and drugs serve as catalyst for cross-border flows between the two border towns. However, the efficiency of the hospital in Galmi (known for its foreign doctors) also families with a critically ill patient to transfer him/her to Galmi hospital in Niger (Shehu M, interview May 2010). Hence, it could be said that attending hospitals in the Nigerien or Nigerian part by both the Nigeriens and Nigerians is usually carried out of necessity. Poverty and critical illness are therefore two key reasons forcing cross border health movement. It could also be assumed in this respect that both Nigeriens and Nigerians of higher income are more likely to go to Galmi hospital even when not in critical condition than Nigeriens and Nigerians that are poor.

\section{Conclusion}

This study examines the role of socio-cultural factors in determining the rate of informal cross-border flows between Nigeria and Nigeria. With specific reference to Illela and Birni N'Konni border communities, the research advance into identifying some of the social and cultural factors influencing informal cross-border flows. The research identified factors like religion, sport, activities of traditional institutions, health factor, bi-monthly security meetings, etc. on the basis of this findings, the research concluded that although such relationship has the capacity to make border area vulnerable to cross-border criminals who may use such flows to achieving their aim, however, if such factors are adequately utilised, Nigeria can improve the security of the area by officially integrating these factors into the official security network of the area. This can be achieved through the provision of infrastructure and social amenities. This should be carried out in a comprehensive manner to the extent that both communities should be so integrated that they believe that the insecurity of Nigeria is directly proportional to the insecurity in Niger. This will help in fostering unity of security consciousness. 
Pakistan Journal of Humanities and Social Sciences, 6(2), 2018

\section{References}

Archibong, M. (2009, August 9). Illela: Smugglers Heaven, Sun Newspaper, Retrieved on 12/10/2009 from http://www.sunnewsonline.com/webpages/festures/travels/2007/aug/09/travels-0908-001.htm

Dankama S.B.G (2004) Nigeria-Niger Border Community Relations: A Case Study of Dankama-Gozoua (M.Sc. Dissertation, Sokoto, Department of Political Science, Usmanu Danfodiyo University, 2004).

Jip, N. (1996) Economic Implication of Seasonal Migration along Nigeria-Niger Border Birnin N'Konni Illela Road 1963-1993. (M.A. Dissertation, History Department, Usmanu Danfodiyo University, Sokoto, 2008).

Khalid S. (2006, August 9). Hope Betrayed? Almajirci and the Menace of Child Abuse in Northern Nigeria, Daily Trust Newspaper, Nigeria.

Illela LEEDS (2008-2010). Illela Local Government Area of Sokoto State, Economic Empowerment \& Development Strategy. A UNDP Supported Programme.

Microsoft Encarta (2009). Citation Guide: APA Style 1993-2008 (DVD), Redmond, WA: Microsoft Corporation.

Muhammad, R.A (2009, May 12). Nigeria: Inside Illela's Booming Grains and Livestock Trade. Retrieved on 12/10/2009 from http://allfrica.com/stories/20090 5120266.html

Nuhu-Koko, A.A (1989). A Geographical Analysis of Transborder spatial interaction: A study of Transborder Trade between Nigeria-Niger Border Settlements. In Asiwaju A.I \& BArkindo, B.M (Eds) Nigeria-Niger Transborder Cooperation, (pp.178-195). Lagos, Malthose press.

Odihi, J.O (1989) Nigeria-Niger Transborder Crossing During Environmental Crisis: Towards Planning for Disaster Mitigation. In Asiwaju, A.I \& Barkindo, B.M (Eds), Nigeria-Niger Transborder Cooperation, (pp.169-176). Lagos, Malthouse press.

Shehu A.T (2004) the Role of Local Government in Rural Development: A Case Study of Illela Local Government. An unpublished project Submitted to the Department of Public Administration, Usmanu Danfodiyo University, Sokoto

Wikipedia Encyclopedia (n.d), Border. Retrieved on 2/03/2009 from http://wikipedia.org/border

Wikipedia Encyclopaedia (n.d), Birnin Konni. Retrieved on 7/10/2009 from http://wikipedia.org/wiki/Birnin-Konni.

Wurma, K. (June 25, 2009) Nigeria, Niger Republic Local Bilateral C'ttee Confab Opens, New Nigerian Newspaper

Zartman, I.W (1965) the Politics of Boundaries in North and West Africa. The Journal of Modern African Studies 3(2), 155-173. Cambridge University press. Retrieved on 01/06/2009 from http://jstor.org/staple/1589700 
Interview List

\begin{tabular}{|c|c|c|c|c|c|}
\hline $\mathbf{S} / \mathbf{n}$ & Name of interviewee & $\begin{array}{l}\text { Approx. } \\
\text { Age }\end{array}$ & $\begin{array}{l}\text { Position } \\
\text { Occupied }\end{array}$ & $\begin{array}{l}\text { Place of } \\
\text { interview }\end{array}$ & Date of interview \\
\hline 1. & Abdullahi Garba & 38 & Illela youth leader & Illela town & July 30, 2009 \\
\hline 2. & Abubakar Ibrahim & 30 & Immigration staff & Sokoto & August.9,2009 \\
\hline 3. & Bello Aliyu & 27 & Immigration staff & Sokoto & Sept. 17,2009 \\
\hline 4. & Dauda Ladan Argungu & 50 & $\begin{array}{l}\text { Asst. Controller of } \\
\text { immigration } \\
\text { charge of Illela post }\end{array}$ & Illela border post & July 29,2009 \\
\hline 5. & $\begin{array}{ll}\text { Garba } & \text { Abdullahi } \\
\text { Ubandawaki }\end{array}$ & 75 & Illela district head & Illela town & July 29, 2009 \\
\hline 6. & Garba Buba Illela & 43 & Farmer & Illela town & July 30, 2009 \\
\hline 7. & Garba Kabo & 39 & Ex-Illela youth leader & Illela town & July 30, 2009 \\
\hline 8. & $\begin{array}{l}\text { Harouna } \\
\text { Bako }\end{array}$ & 40 & $\begin{array}{l}\text { Director } \\
\text { regional,Amfani } \\
\text { Radio }\end{array}$ & Konni town & July 30, 2009 \\
\hline 9. & Ishaya Musa & 41 & Police officer & Illela border post & $\begin{array}{l}\text { July } 29 \text { and } 30 \text {, } \\
2009\end{array}$ \\
\hline 10. & Junaidu Abdullahi & 29 & Civil servant & Sokoto & August2,2009 \\
\hline 11. & Kasimu Audu & 42 & $\begin{array}{l}\text { Vice-chairman kabu- } \\
\text { kabu, Konni }\end{array}$ & Konni town & July 29, 2009 \\
\hline 12. & Muhammad Sani & 39 & Driver & Konni town & July 292009 \\
\hline 13. & Muhammadu Nuhu & 43 & $\begin{array}{l}\text { Info. Officer, Illela } \\
\text { L/govt. }\end{array}$ & $\begin{array}{l}\text { Illela local } \\
\text { government }\end{array}$ & $\begin{array}{l}\text { July,29 and } 30 \\
2009\end{array}$ \\
\hline 14. & Muhammd Usmanu & 43 & \multirow{2}{*}{$\begin{array}{l}\begin{array}{l}\text { Driver } \\
\text { Secretary, Illela } \\
\text { petrol } \\
\text { association. }\end{array} \\
\end{array}$} & Sokoto & August. 9, 2009 \\
\hline 15. & Musa Dan Maliki & 40 & & Illela town & July 30, 2009 \\
\hline 16. & $\begin{array}{lll}\text { Sani } & \text { Hassan } & \text { Mai } \\
\text { Kasset } & & \end{array}$ & 48 & $\begin{array}{l}\text { V/Chairman, Konni } \\
\text { traders }\end{array}$ & Konni town & July 30, 2009 \\
\hline 17. & $\begin{array}{ll}\text { Tankou } & \text { Ahmadou } \\
\text { Rufai } & \\
\end{array}$ & 53 & $\begin{array}{l}\text { Secretary, Konni } \\
\text { local government }\end{array}$ & $\begin{array}{l}\text { Konni L/govt. } \\
\text { secretariat }\end{array}$ & July 30,2009 \\
\hline 18. & Tonyon, D.M & 50 & $\begin{array}{l}\text { Chief Superintendent } \\
\text { of Customs in charge } \\
\text { of the Post }\end{array}$ & Illela border post & July 29, 2009 \\
\hline 19 & Anonymous & 27 & Security official & Sokoto & Sept. 17,2009 \\
\hline 20 & Shehu, A. & 52 & Trader & $\begin{array}{l}\text { Old market } \\
\text { Sokoto }\end{array}$ & November 20, 2009 \\
\hline 21 & Shehu, Mukhtar & 46 & $\begin{array}{lr}\text { Chief } & \text { Medical } \\
\text { Director, } & \text { Daboe } \\
\text { Clinic, Illela } & \\
\end{array}$ & Illela town & April 5, 2010 \\
\hline 22 & Sani, Lawali & 27 & Trader & $\begin{array}{ll}\text { Old } & \text { market } \\
\text { Sokoto } & \\
\end{array}$ & November 20, 2009 \\
\hline 23 & Yusuf Aliyu-Koko & 38 & Car dealer & Sokoto & March,14 2010 \\
\hline
\end{tabular}

